\title{
教育改革論議に対する教員層の関心と意見
}

\author{
松 本 良夫
}

\section{1. 主題と方法}

\section{(1) 主 題}

昭和50年代には，中学校を中心に「校内暴力」の嵐が吹き荒れた。このような環境 のなかで，この「荒れる学校」といら事態が直接の引き金になって，昭和59年 9 月に 首相から教育改革に関する䛇問が臨時教育審議会に出された。こうして, 教育改革が 公式に政治日程にのぼってきたのである。以後 2 年半余の時が経 過し, 本年 4 月に 「第二次答申」が出された。しかし，まだ今回の臨教審改革の帰赹は定かでない。い ずれにせよ，教育改革は，「世論」の赴くところにより結着をつけるべきであろう。

ところで，この件に関して世論はどう動き，どのように固まってゆくのだろうか。 世論とは，国民全体の意見であるが，世論調査に表現された意見がつね秋争点に結着 をつける意見になるとは限らない。どんな争点についてる，その件に直接的な利害関 係をるつ「業界」の意見が大きな力をるつのが通例である。教育改革についていえば， 「教育界」の意見がこれにあたる。審議の結果，どのような改革が実施されようとも， 直接的に，具体的な影響を受けるのは，教師たちである。したがって，当然，教師た ちは改革論議の動向に多大の関心をるたざるを得ない立場にある。しかるに，これま でのところ教育界，とくに教員層の方から積極的に意見が表明されているようには思 えない。今回の臨教審方式では，発端から教育界はなかば眯外され，むしろ被告席側 飞まわされて拉り，審議の経過を横目でにらみながら，息をひそめてその成り行きを らかがっているといった感がつよい。それでよいのか，大変気になる点である。

筆者らの研究グループ(教職社会学研究会)は, ちょらどこの期間に, 文部省の科学 研究費の助成を受け，教員調査をすすめてきた(1)。この研究は，中学校教員の役割不 適応と役割革新を主題とするものであるが，中学校教員だけでなく，中学に連接する 小学校・高校の教員および中学校の管理職をも調査の対象としている。そのなかで,

東京学芸大学 
現下の教育改革論についての教員層の関心と意見を探る若干の設問を用意した。これ は教員の「世論調査」を意困したのではなく，現下の話題の焦点をひきあいに出し て, 教員層の意識態度の特性を探ろうとしたものである。しかし，本稿では，本誌の 特集テーマに合わせて，この部分を，教員層の教育改革問題に関する「世論」として 読むことにしたい。

要するに本稿では, われわれが央施した調查の結果を主な材料にして, 現下の教育 改革論議に対する「業界」の意見の構造, 業界世論と一般世論との関連について考察 を加えてみたい。本稿で，検討を予定しているのは，以下の諸点である。

i ）一般教員と管理職との関心・意見の異同。

ii）退職教員と現職教員との関心・意見の異同。

iii）教員層の意見と一般世論との相遀。

iv）「臨教審」期待派と非期待派の意見の相違。一以上の 4 点である。

(2) 方 法

ここで，資料としてもち出す一連の調査について，その概要を記しておきたい。小 学校, 中学校, 高校の一般教員の調査は, いずれも東京都の公立学校教員のなかから 無作為抽出した標本を対象とした。抽出率は, 小学校が $1 / 30$ (二段抽出), 中学・高校 は1/10である。中学校教員調查は昭和59年11月, 小学校・高校調查は昭和 60 年11月に 実施した。いずれも，郵送法による質問紙法で，回収率は小； $31.8 \%$, 中； $35.6 \%$ ， 高； $37.9 \%$ であ。

中学校管理職の調査は, 1 都 3 県の公立中学の校長・教頭を対象とした。抽出率は $2 / 3$ ，実施時期は昭和60年11月である。これも郵送法による質問紙調㚗で，回収率は $45.8 \%$ である。以上， 4 種の調査のうち, 昭和60年に実施した小学校・高校の一般教 員調査, 中学校管理職調査で, 教育改革についての意見を求めている。前年に実施し た中学校教員調査には，この関係の質問はしていない。したがって，後述の資料で は，主として小学校・高校の教師と中学の管理職の回答を提示することになる。な お, 中学校教員の意見は, 他の調査 (後述の退職教員調查) の結果から推測して, 多 くの場合小学校と高校の中間にあると考兄られる。

以上の調查のほかに, 日教組が実施した「退職教員」の調査の結果を適宜参照, 引 用する。この調查は，昭和61年 1 月， 日教組が全国の退職教員（「退教協・退婦協」 の会員）を対象に実施したもので，筆者がさきに行った調査とほぼ同じ設問が一部と り入れられている。この調査の抽出率は $1 / 20$, 回収率は $42.7 \%$ であ。

これら一連の教員調査の結果と比較する一般市民の意見は, 新聞社が実施した世論 調査の結果から引用する。

\section{2. 資料と考察}

\section{（1） 状況認識と改革への期待}


本題に入るまえに，一連の調査の結果から，初等・中等教育にたずさわる教員の， 最近の状況につい摘記しておこう。

小・中・高の教員たちは，「荒れる学校」といわれる事態の中で教育実践にとり組 んでいる。教師たちは，児童生徒の問題行動を身近に見ながら職務にあたっている。

「いじめ」の見聞率（「しばしば」「とさどき」みられるとの回答の割合）は，小； $61.4 \% ， 中 ; 83.5 \%$ ，高；34.8\%である。登校拒否の見聞率は，小； $38.0 \%$ ，中； $74.5 \%$ ，高； $67.8 \%$ となっいる。

また，少なからぬ教師が，生徒から反抗を受けている。これまでに，「ひどい授業 妨害」を受けたことがあると答えた教師は，小； $8.9 \%$ ，中； $34.9 \%$ ，高；21.5\%とな っている。

このような困難な状況から，「不適応」兆候を訴える教師も決して少なくない。こ の 1 年間に「授業のとさ気が重い」と感じたことのある教師は，小；16.2\%，中； $30.2 \%$ ，高； $36.3 \%$ とっている。同じく「勤務が苦痛でしかたがない」と感じたこ とのある教師は小；8.8\%，中；11.9\%，高；14.8\%となっている。

このように，今日は教師受難の時代である。したがって，多分，大部分の教師がこ の現状を変革する必要性を感じていると想像される。退職教員調査によると，元教員 の95\%までが「今の学校教育」について改革の必要性をみとめている(「大いに必要」; $26 \%$,「改革する必要のあるところもある」; 69\%)。

しかし，この認識は，必ずしも現在進行中の「臨教審」による改革への期待とは結 びついていない。表 1 は,「臨教審」による教育改革への期待の程度を表示したもので ある。一般教員では，「期待派」はきわめて少ない（小学校；約 $9 \%$, 高校; 約 $18 \%$ )。 これに対し，中学校の管理職では「期待派」が 6 割と半数を上まわっているが，積極

表 1 「臨教審」による教育改革への期待（\%)

\begin{tabular}{|c|c|c|c|c|c|}
\hline & $\begin{array}{l}\text { 小学校 } \\
\text { 教 員 }\end{array}$ & $\begin{array}{ll}\text { 高 校 } \\
\text { 教 員 }\end{array}$ & $\begin{array}{l}\text { 中学校 } \\
\text { 管理職 }\end{array}$ & $\begin{array}{ll}\text { 退 } & \text { 職 } \\
\text { 教 員 }\end{array}$ & 市 民般 \\
\hline 1. 大いに期待している & 4.7 & 1.5 & 20.7 & 4.5 & 5.5 \\
\hline 2. まあ期待している & 13.2 & 7.4 & 40.2 & 27.8 & 34.6 \\
\hline$(1+2)$ 期待派 & 17.9 & 8.9 & 60.9 & 32.3 & 40.1 \\
\hline 3. どちらともいえない & 17.6 & 14.6 & 12.1 & 16.9 & 9.9 \\
\hline 4. あまり期待していない & 41.8 & 37.6 & 24.8 & 36.8 & 40.1 \\
\hline 5. まったく期待していない & 22.4 & 38.4 & 1.9 & 13.8 & 9.9 \\
\hline$(4+5)$ 非期待派 & 64.2 & 76.0 & 26.7 & 50.6 & 49.1 \\
\hline 全 & 100.0 & 100.0 & 100.0 & 100.0 & 100.0 \\
\hline$(\mathrm{N})$ & ( 340$)$ & ( 391) & $(734)$ & ( 1069) & - \\
\hline
\end{tabular}

注 *「一般市民」の項は，読売新聞の世論調查（昭和61年 2 月）による。 
的な期待派は 2 割程度にとどまる。退職教員の場合は，期待派が 3 割強となっている が，これは元「一般教員」と元「管理職」の両方が含まれているためと考兄られる。 退職教員についても, 元「管理職」には期待派が多い(54\%:27\%)。読売新聞の世 論調查（昭和61年 2 月）によると，国民の 4 割が「臨教審」に期待しているものの， それを上まわる約半数はあまり期待していないという結果が出ている。

「臨教審」による教育改革は, 現内閣の「目玉」政策の一つとして喧伝されている ものの, 国民一般も，一般教員もさ活ど期待して扔らず，教員のうち管理職層がわず かに期待しているといったところが現状といえよう。

ここで期待の有無について,やや詳細にみてみよう。小学校教員では,女性(13.4\%) よりも男性 (26.7\%) の方に期待度がやや高い。年秢段階別にみると，50代で期待率 が高くなっている（約30\%-20４0代までは13\%前後）。高校教師の場合も，男性 の方が期待度が高いが，年龄段階による差はみられない。中学校管理職では，校長の 方が教頭より期待派がやや多い（校長63\%，教頭58\%)。退職教員調查の結果により， 期待率を校種別にみると，小；33.7\%，中； $29.7 \%$ ，高；32.8\%と大同小異である。

以上述べたように，教師たちの状況が改革を要すると認識されているのに，目下進 行中の改革に教員層が期待できないでいる点, 管理職と一般教員層との間にかなりの 認識のズレがある点は，今回の教育改革の今後に問題を残すことになろう。

（2）教員の役割葛藤と準拠集団

教員層が，現下の教育改革にこれほど冷淡なのは，なぜであろらか。これには，こ

表 2 役割葛藤と準拠集団 $(\%)$

\begin{tabular}{|c|c|c|c|c|}
\hline & $\begin{array}{l}\text { 小学校 } \\
\text { 教 }\end{array}$ & $\begin{array}{l}\text { 中 学 校 } \\
\text { 教 }\end{array}$ & 高校教員 & $\begin{array}{l}\text { 中学校 } \\
\text { 管 理 職 }\end{array}$ \\
\hline \multirow{3}{*}{$\begin{array}{l}<\text { 役割葛藤・違和感 }> \\
\text { 管理職 の学 校運 営方針 } \\
\text { 教育委員会の指導方針 }\end{array}$} & \multirow{4}{*}{$\begin{array}{l}25.6 \\
23.8 \\
29\end{array}$} & \multirow{4}{*}{$\begin{array}{l}24.2 \\
20.8 \\
43.0\end{array}$} & \multirow{4}{*}{$\begin{array}{l}32.2 \\
52.2 \\
60.1\end{array}$} & \multirow{4}{*}{$\begin{array}{l}- \\
1.9 \\
5.7\end{array}$} \\
\hline & & & & \\
\hline & & & & \\
\hline 国 の 教 育 政 策 & & & & \\
\hline 教 員 組 合 の 方 針 & - & 20.9 & - & 23.3 \\
\hline \multicolumn{5}{|l|}{ ＜準拠集団> } \\
\hline 文 & 1.8 & 1.6 & 1.8 & 14.9 \\
\hline 育 委 員 & 4.4 & 4.0 & 3.8 & 72.1 \\
\hline 組 & 7.1 & 8.0 & 7.2 & 1.2 \\
\hline 長 （会） & 30.0 & 25.6 & 16.9 & 77.0 \\
\hline 職場 の 同 僚 & 77.9 & 84.4 & 83.4 & 53.1 \\
\hline 全 & 100.0 & 100.0 & 100.0 & 100.0 \\
\hline$(\mathrm{N})$ & $(340)$ & ( 679) & ( 391) & ( 734) \\
\hline
\end{tabular}


教育改革論議に対する教育層の関心と意見

れまでの学校教育に関する施策への, 積年の不満や違和感が底流にあるように思われ る。とくに今回の改革の「すすめ方」に文られる教育界, とくに教育現場の意見を積 極的に聴こうとする姿勢の欠如が，この違和感をさらに増大させたように思われる。

表 2 の上段は, われわれの実施した一連の調査のなかから，「管理職の学校運営方 針」,「教育委員会の指導方針」,「国の教育政策」への違和感の部分をとり出し比較し たものである。このなかで，とくに「国の教育政策」に対して違和感を感じている教 員の割合の高い点が目立つ。小・中学校では，この率が $43 \%$ 程度だが，高校では $60 \%$ にも達する。「国の教育政策」ともなると, 相手も大きく, 内容も広範にわたるので 違和感も大きくなるとしても, この数字の大きさは考光させられる。一方, 中学校の 管理職では，国の教育政策に違和感を表明した者は $6 \%$ ほどと低い。この点にも，一 般教員と管理職との立場と意識の相違がはっきりあらわれている。

表 2 の下段は, 準拠集団についての調查結果の一部である。数字は, この表に表示 したもの以外（友人，家族など）を含めた各項目から，「教職生活の上で，困ったこ とや迷うことが起きた場合，……との意見や考光を参考にする」人々（集団・機関） を, 選んでもらった結果である (重複回答)。一般教員では, 「職場の同僚」を準拠集 団とする割合が压倒的に高いが，管理職では，「校長会」や「教育委員会」を隼拠集 団とする割合が高い。

これらの点について，一般教員と管理職とのあいだにある程度の相違があること は，それぞれの立場を考えれば理解できるが，これほど大きな違いがあっては，各学 校組織の教師集団としての一体感はもちにくいと想像される。

\section{（3）教员屈の関心の焦点}

一般教員は，今回の教育改革にあまり期待していないことは前述のと拉りである 表 3 改革検討課題への関心（\%)

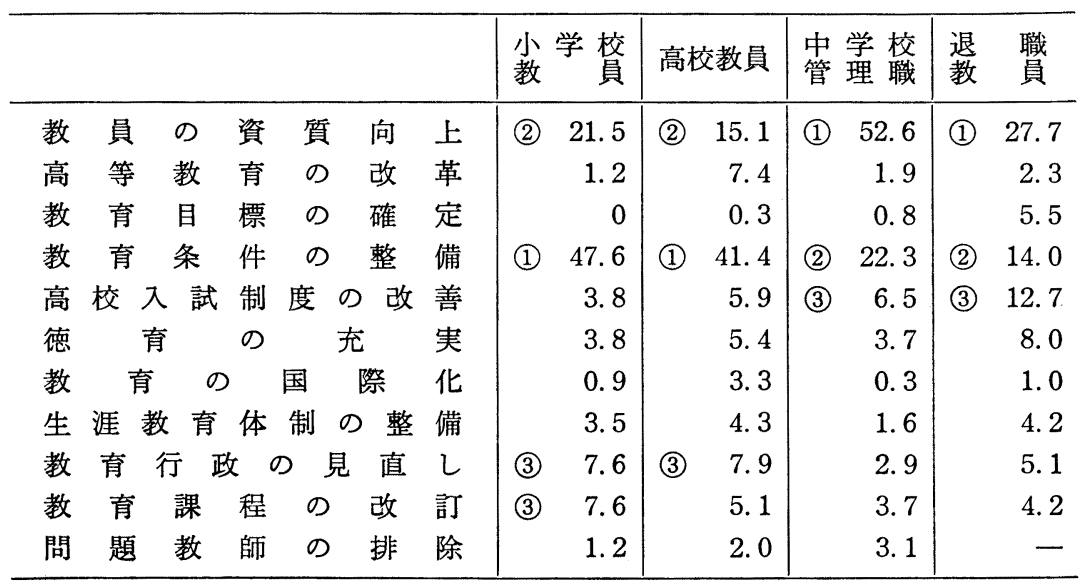


が，それはとれとして，教師たちは，現下の改革論で検討されている課題のうち，ど の点に関心をもっているのだろらか。

表 3 は, この点についての反応結果の一端である。「臨教審」は審議の途中で, 論 点を八つの「検討課題」に整理している。われわれの調查では, このうちの 6 項目に, 他の 5 項目を追加し, 表示の11項目のなかから, 関心の高い順に 3 項目まで挙げても らった。表 3 は，第 1 順位に選ばれた項目について，その割合と順位（丸で囲んだ数 字）を示したものである。

小学校教員では，「教育条件の整備」への関心がもっとも高く，「教員の資質向上」 がこれについでいる。第 3 位は，「教育行政の見直し」と「教育課程の改訂」(同率) であった。高校教師のばあいも, 関心の様相は, 小学校教師のばあいと大同小異であ

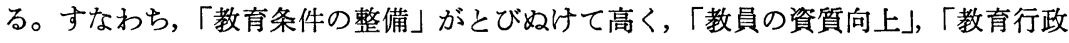
の見直し」がこれにつづいている。ただ，高校の場合は小学校に比し「高等教育の改 革」への関心が比較的高い。

このように，一般教師のばあい，一部の者は「教員の資質向上」に強い関心をもっ ているものの, 多くの教師は「教育条件の整備」や「教育行政の見直し」に強い関心 を抱いている。第 2 順位の回答でも，これらの項目は比較的多く選ばれているが，そ れ以外では，「高校入試制度の改善」が，小学校教師にも，高校教師にも関心をもた れている。

中学校管理職の関心は, 小・高の一般教師とはかなり異なっている。表にみられる と拉り，「教員の資質向上」が, 半数以上の回答者から第 1 位に選ばれている。ついで, 強い関心をもたれているのは「教育条件の整備」である。大多数の関心は，この 2 点 に集中している。第 2 順応の回答（表は省略）では，(1)教育条件 (21.9\%)，(2)高校入 試 (15.3\%)，(3)教員の資質 (14.6\%)，(4)徳育の充実 (13.2\%)の順となっている。

ちなみに，退職教員のばあいも，ほぼ同じ方式で調查されているが, 関心の順位は， (1)教員の資質，(2)教育条件の整備，(3)高校入試の改善の順となっている。なお，われ われの調查では, 教育条件の項目は「学級規模等の教育条件の整備」としたのに対し， 退職者調查では，ただ「教育条件の整備」としているので，この項目の選択が減少し たと考兄られる。退職教師の回答を，退職時の職位別にみると，管理職では(1)教員の 資質 $(36.7 \%)$, (2)教育条件の整備 $(14.0 \%)$, (3)徳育の充実 (10.2\%) の順なのに対 し，「教諭」では(1)教員の資質 (24.9\%), (2)教育条件の整備 (14.7\%), (3)高校入試 の見直し (13.8\%) の順となっている。な怙，校種（小・中・高の別）による違いは， 高校入試への関心以外にはあまりみとめられない。

このように，一般教師と管理職とのあいだでは，「臨教審」改革への全般的な期待 度だけではなく, 改革の論点への関心も異なっている。一般教師が「教育条件」や 「教育行政」に強い関心をもっているのに対し，管理職の関心の焦点は，「教員の資 質」と集中している。この関心の相違が，「臨教審」改革への期待度を分けていると 
も考えられる。

ところで，一般国民の関心は，どうであろらか。読売新聞の世論調查（昭和 61 年 2 月）では，「いま学校教育に対して不満に思らこと，改革が必要だと思うこと」をき いている(重複選択)。その結果によると，(1)「いじめ」(56.7\%), (2)教師の質 (53.3 $\%$ ), (3)校内暴力・非行 (48.6\%), (4)詰め込及教育 (38.5\%), (5)道徳教育 (36.0\%), (6)偏差値教育 (33.4\%) などが比較的多くの人々の関心を集めている。

このように，一般国民，一般教師，管理職と並べてみると，三者三様の関心の構造 をもっていることがわかる。これを共通の認識にまとめあげるのは容易ならざること である。しかし，まず論議の出発点に拉いて，この「相違」自体を相互に知っでく ことが大切であろう。

われわれは, 前記とは別に, むら一つの形で教員層の関心の所在, あるいは現状に ついての問題意識を探ってみた。「教育の制度改革もさることながら，わが国の教育 や学校をよくするためには，教育現場での日常的な営みや慣行にす改善すべき点が少 なくないと思われます」と前置きして，表4亿表示した各項目のなかから，「問題だと 思う程度」の強い順に 3 項目まで選んでもらった。表 4 は, 第 1 順位として選ばれた 割合を示している。

表 4 現状の要改善点（\%)

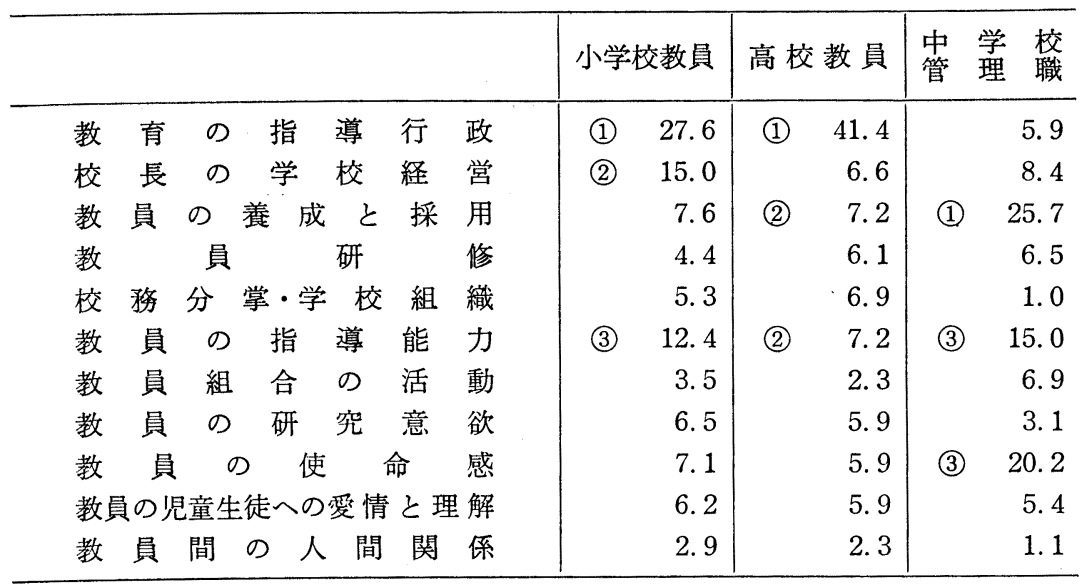

小学校教師では, (1)教育の指導行政 (27.6\%), (2)校長の学校経営の仕方(15.0\%), (3)「教員の指導能力」 (12.4\%) が, 現状の要改善点として指摘されている。第 2 順 位の回答では, これらのほかに, 「校務分掌・学校組織」「教員の児童への愛情と理 解」などが比較的上位に出てくる。

高校教師の反応は, 小学校のばあいともやや異なる。高校教員では, 「教育指導行 
政」に問題を感じている者が際立って多い。第 2 順位の選択を含めてみると，これ以 外では, 校長の学校経営, 教員の養成と採用, 教員の指導能力, 教員の研究意欲など の諸点が，改善を要する「問題点」として意識されている。

中学校管理職の，この質問に対する回答は，前二者とはまたかなり異なる。一口に いうと, 管理職の関心はもっぱら「教師」の問題に集中している。すなわち, 第 1 順 位でも, 第 2 順位でも，「教員の養成と採用」,「教員の指導能力」,「教員の使命観」 が上位 3 位に入っている。

現状の要改善点についての，一般教員と管理職との認識の相違は，その職位にとも なら職務の違いからくるものと考兄らるが，単に「立場」の違いだけに畄せられな いであろう。相互に，自己の立場を棚上げして，相手の「不備」を非難し合うだけで は，児童・生徒にとって「よい」解決は望めない。この点についても，立場の違いを 超えた次元一一児童・生徒に対する教育指導の組織者, 実践者としての次元一一゙の 意見の調整が望まれる。

\section{（4）主要争点についての意見}

臨教審は，「当面の具体的改革提言」を早急に打ち出し，これを「今次教育改革の 突破口ないし端緒」としょうとしているようである。最終的に，どのような具体的提 案が出されるかは未定であるが，審議の途中で，いくつかの案が姐上にのぼり，新聞 等で報道され，関係者の論議の的となった。

表 5 主要争点についての意見 $(\%)$

\begin{tabular}{|c|c|c|c|c|c|c|c|}
\hline & & & $\begin{array}{l}\text { 小学校 } \\
\text { 教 員 }\end{array}$ & $\begin{array}{ll}\text { 高 } & \text { 校 } \\
\text { 教 } & \text { 員 }\end{array}$ & $\begin{array}{l}\text { 中学校 } \\
\text { 管理職 }\end{array}$ & $\begin{array}{l}\text { 退 校 } \\
\text { 教 員 }\end{array}$ & 市槃 \\
\hline \multirow[t]{2}{*}{ 1) } & 6 年制中等学校の設置 & 賛 & 47.7 & 32.2 & 50.2 & 45.7 & - \\
\hline & & 否 & $(50.3)$ & $(64.9)$ & $(48.9)$ & $(49.1)$ & - \\
\hline \multirow[t]{2}{*}{ 2) } & 単位制高校の設置 & 賛 & 51.8 & 56.3 & 77.7 & 46.0 & 一 \\
\hline & & 否 & $(40.6)$ & $(42.0)$ & $(19.0)$ & $(45.2)$ & - \\
\hline \multirow[t]{2}{*}{ 3) } & 初任者研修制度の創設 & 賛 & 56.2 & 44.7 & 93.6 & 51.6 & 65.7 \\
\hline & & 否 & $(40.3)$ & $(54.0)$ & $(5.3)$ & $(43.7)$ & $(24.4)$ \\
\hline \multirow[t]{2}{*}{ 4) } & 教員適格審查制度の創設 & 賛 & 25.3 & 28.9 & 79.3 & 39.9 & 56.9 \\
\hline & & 否 & $(62.0)$ & (69.3) & $(19.6)$ & $(55.1)$ & $(30.0)$ \\
\hline \multirow[t]{2}{*}{ 5) } & 小•中学校の学区の自由化 & 賛 & 26.2 & 26.0 & 21.9 & 22.5 & - \\
\hline & & 否 & $(70.6)$ & $(71.1)$ & $(77.3)$ & $(71.9)$ & - \\
\hline
\end{tabular}

われわれの調查では, 表 5 に表示した五つの案ないしは争点について，教員層の意 見をきいた。その結果を，順次みてゆくことにしたい。

1） 6 年制中等学校の設置について—この点についての教員層の意見は，賛成一反 対の真二つに分かれる。小学校教員, 中学校管理職, 退職教員の意見とも, 賛否ほぽ 
半数ずつに分かれる。高校教員の $2 / 3$ はこの案に「反対」している。中学の一般教員 の意見はきけてないが，退職教員のらち元中学校教員の意見も賛成 $45 \%$ ，反対 $50 \%$ に 分かれている。この反応からみても，この案については，その趣旨拉よび具体的方式 を十分検討する必要があろう。

2）単位制高校の設置について—この点についても，一般教員層の意見は，賛否両 論に分かれている。ただ，前項の「6 年制中等学校の設置」にくらべれば，賛成者の 割合が高く，とくに高校教員では56\%が賛意を表している（反対は42\%)。なお，こ の案についての中学校管理職の意見は，一般教員層と異なり，大きく賛成の方に傾い ている。とくに東京都の中学の管理職では賛成者の割合 (83.5\%) が高い。この案に ついては一般教員と管理職とで意見の分かれてる点が，前項との相違点である。

6 年制中等学校と単位制高校の設置とは，高等学校のあり方に関わるワンセットの 問題であり，この点に関して教員層の意見が大きく分かれている現状からみて，両案 の再考が求められよう。

3）初任者研修制度の創設について—この点に関する教員層の意見は，それぞれの 区分ごとに異なった様相をみせる。小学校教員の意見は, 賛否に分かれるるのの, 賛 成者の方がやや多い。これに対し，高校教員の意見は，反対の方に傾いている。この 差異は，学校段階による研修条件や研修意欲の違いのあらわれと考兄られる。一方， 中学校管理職の意見をみると，この件については $94 \%$ までが賛意を表して拉り，この 制度を強く希望していることがわかる。な⿰，94\%の内訳は，「大いに賛成」58\%，

「どちらかとい光ば賛成」36\%である。

ちなみに，この点については，世論調査による一般国民の意見がある。読売調査 （前述）によると，「賛成」；65.7\%，「反対」；24.4\%となっている。

教員の研修, とくに初任者の研修を充実することは大切なことであり, 誰しも反対 しないであろらが，要はどのような方式で充実するかが問題であり，今後その具体的 条件をつめてゆく必要があろう。

4）教員適格審查制度の創設について—この点については，この案が一部委員から 提言された当時, 大いに論議を呼んだ。第二次答申段階では, 教育委員会の役割の見 直しと活性化とからめてこの件を検討することとなったよらであるが，この懸案自体 がとり下げられたわけではなさそらである。この件関する今後の扱いはとるかく， 当時伝えられたところの「適格審」の創設について，教員層の意見をさいた。

この件に関しては，一般教員の反発はつよく，小学校教員では 6 割強，高校教員で は約 7 割が反対している。これとは対照的に，中学校管理職では，約 8 割（東京都だ けに限ると $89 \%$ ）が賛成しておらり，事柄が事柄だけに一般教員の意見と管理職の意見 は真向から対立している。この点についての国民世論は, その中間にあり，読売調査 によると，賛成約 6 割，反対 3 割となっている。

教員制度のなかに，「不適格」者に対する処遇を決める仕組みが必要なことは論を 
またないが，それを公正，的確に実施できる方式を確立しないかぎり所期の目的を達 せないであろう。

5）小・中学校の学区の自由化について一一臨教審による教育改革論議は, 当初, 教 育の「自由化」方針に先導されてスタートしたかにみえたが，その後この線は後退し たと伝えられている。学校教育の自由化の考方方から出てきた案の一つに,「小・中 学校の学区の自由化」案がある。この点については，一般教員の意見も管理職の意見 も一致して, 消極的である。小学校教員, 高校教員, 中学管理職のいずれの群でも, 反対が 7 割をこえている。とくにこの点に関しては，管理職の方が反対の意向がつ よい。このような反応は, この案の賛同者からは, 教育界の現状維持志向, 保守性と 批判されるかもしれないが，そらとばかりはいえないと筆者は考える。一定年龄段階 のすべての児童・生徒に「共通の教育」を保障するといら使命と教育指導の個性化, 自由化の理念をどう両立させ，調和させるかをさらに追求すべきであうう。

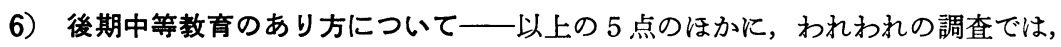
後期中等教育のあり方および小・中・高のアーティキュレーションに関する意見をき いているので, この点を付記しておく。

後期中等教育のあり方に関しては，「高校を全入制にすべし」と「中卒後には，高 校以外にもっと多様な進路を用意すべし」という対立する意見を提示し，どちらに賛 成かをさいている。小学校，中学校，高校の教員とも「全入制」支持者は少ない（小； $38.2 \%$ ，中； $20.5 \%$ ，高；16.1\%)。学校段階別には，上級段階ほど，「全入制」支持 者は減っている。な拈，中学校管理職の全入制賛成者は $8.6 \%$ でった。この点に関 しては，教員層の大半は「多様化」を支持している（小； $60.0 \%$ ，中； $78.9 \%$ ，高； $80.3 \%$ ，中・管; $94.4 \%)$ 。

7）小・中・高のアーティキュレーションについて—初等・中等教育の三つの学校 段階間の接続関係については，「小・中のつながりを緊密にすべし」と「中・高のつ ながりを緊密にすべし」との両意見から賛成する方を選択してもらった。小学校, 中 学校の教員では，「小・中のつながり」を強調する意見が圧倒的に多かった（小； $74.4 \%$ ，中 ; $72.9 \%)$ 。しかし，高校教員では「中・高のつながり」を強調する意見 の方が多い $(56.8 \%: 35.3 \%)$ 。なお，中学校管理職の意見は,「小・中」強調 $66.0 \%$, 「中・高」強調 $30.6 \%$ と拉よそ $2 ： 1$ 亿分かれた。このように，小学校と高校の教師 は，それぞれ自己の関係する学校段階と中学との接続を強調しているが，両者に挟ま れて義務教育と中等教育の「二重国籍」を余儀なくされる中学校教師は, どちらかと いうと小学校とのつながりを重視している。教科担任制という点では, 中学と高校に 共通性があるが，小学校と中学校は設置主体が同一自治体（市区町村）であり，両段 階の教師間の接触も多いため「小・中」の連携がより強く意識されるものと考兄られ る。

（5）臨教審期待派と非期待派の意見の相違 
教育改革論議に対する教育層の関心と意見

\section{1）検討課題・現状の要改善点についての関心の相運}

前項までで，われわれの一連の調査でとりあげた教育改革関連の質問への回答を一 通り紹介してきたが，最後に臨教審期待派の意見と非期待派の意見の相違を検討した い。

表 6 「臨教審」期待派と非期待派との関心の相違（\%)

\begin{tabular}{|c|c|c|c|c|c|c|}
\hline & \multicolumn{2}{|c|}{ 小学校教員 } & \multicolumn{2}{|c|}{ 高校教員 } & \multicolumn{2}{|c|}{ 中学校管理職 } \\
\hline & 期待派 & 非期待派 & 期待派 & 非期待派 & 期待派 & 非期待派 \\
\hline$<$ 検討課題 $>$ & & & & & & \\
\hline 教員の資質向上 & 41.0 & 14.2 & 22.9 & 14.1 & 58.8 & 39.3 \\
\hline 教 育 条 件 の 整 備 & 24.6 & 54.1 & 20.0 & 46.1 & 16.6 & 32.1 \\
\hline 教育行政の見直 し & 4.9 & 10.6 & 2.9 & 8.4 & 3.1 & 3.6 \\
\hline 教 育 課 程 の 改訂 & 11.5 & 6.9 & 14.3 & 3.7 & 3.8 & 3.1 \\
\hline ＜要改善点> & & & & & & \\
\hline 教 育 の 指 導 行 政 & 8.7 & 37.6 & 17.1 & 48.1 & 5.1 & 7.7 \\
\hline 校長の学校経 営 & 13.1 & 17.9 & 0.0 & 7.4 & 7.8 & 11.2 \\
\hline 教 員 研 修 & 6.6 & 2.3 & 11.4 & 5.1 & 7.2 & 4.6 \\
\hline 教 員 の 指 導 能 力 & 14.8 & 8.7 & 20.0 & 6.1 & 14.1 & 15.8 \\
\hline 教 員 の 使 命 感 & 18. 0 & 4.1 & 5.7 & 4. 4 & 22.4 & 13.8 \\
\hline 児童生徒への愛情と理解 & 9.8 & 5.5 & 14.3 & 5.1 & 4.5 & 7.7 \\
\hline 全 & 100.0 & 100.0 & 100.0 & 100.0 & 100.0 & 100.0 \\
\hline$(\mathrm{N})$ & ( 61) & $\mid(218)$ & ( 35) & ( 297) & $(447)$ & $(196)$ \\
\hline
\end{tabular}

表 6 は, 各調查区分ごとに, 臨教審改革への「期待派」と「非期待派」との, 教育 改革問題への関心や意見の相違を示したものである。この表は前出の表 3 （改革検討 課題への関心）と表 4（現状の要改善点）に対応するるのであるが，期待派・非期待 派間に差のみられない項目は省いた。

検討課題についての関心のらち, 期待派の関心が 非期待派を上まわる項目は，「教 員の資質向上」と「教員課程の改訂」の二項目である。逆に，非期待派の方がつよい 関心をもっているのは,「教育条件の整備」と「教育行政の見直し」である。

また，現状の要改善点についてみると（表 6 の下段)，期待派が指摘しているのは， 「教員の指導能力」,「教員研修」「教員の使命感」などの各項目である。これに対し， 非期待派が改善を要する点として指摘しているのは，「教育の指導行政」や「校長の 学校経営方針」である。

こうみてくると，期待派には，現行の制度的体組の中で，教員の努力・工夫により 事態の改善を計ろらとする意識の持ち主が多いのに対し, 非期待派には教育行政や学 
校経営のあり方に変更を求める意識の持ち主が多いことがわかる。教育制度の抜本的 改革をめざす臨教審改革への期待派が「現状肯定的」で，非期待派が「現状否定的」 という構図は何とも皮肉である。この点が, 今回の改革論議の, わかりにくさの一因 であらう。

\section{2）主要争点についての意見の相连}

最後に, 今回の改革論議で出てきた主要な争点についての，期待派と非期待派の意 見の相違をみてみよう（表 7 )。

表 7 「臨教審」期待派と非期待派との意見の相違一賛成率一（\%)

\begin{tabular}{|c|c|c|c|c|c|c|}
\hline & \multicolumn{2}{|c|}{ 小学校教員 } & \multicolumn{2}{|c|}{ 高校教員 } & \multicolumn{2}{|c|}{ 中学校管理職 } \\
\hline & 期待派 & |非期待派 & 期待派 & 非期待派 & 期待派 & 非期待派 \\
\hline 6 年 制 中 等 学 校 & 68.9 & 41.3 & 68.6 & 27.3 & 53.7 & 45.9 \\
\hline 単 位 制 高 校 & 63.9 & 45.4 & 74.3 & 43.9 & 80.4 & 74.0 \\
\hline 初 任 者 研 修 制 度 & 91.8 & 40.4 & 82.8 & 35.7 & 96.2 & 89.3 \\
\hline 教 員 & 67.2 & 23.8 & 68.5 & 21.6 & 83.2 & 69.9 \\
\hline 学 区 の 自 由 化 & 47.6 & 19. 7 & 31.4 & 23.9 & 23.2 & 21.9 \\
\hline 高 校 全 入 & 32.8 & 53.2 & 8. 6 & 19.1 & 6.8 & 10.7 \\
\hline
\end{tabular}

全般的にみて，期待派は，各具体案について「賛成」の意見が多い。とくに，「6 年制中等学校の創設」「初任者研修制度」,「教員適格審」については, 期待派と非期 待派の賛否の差が大きい。ただし，中学校管理職についみると，ぞの項目についても 期待派之非期待派の意見の差はさほど大きくない。表示の五つの争点のうち，「学区 の自由化」については，期待派の賛成率も概して低い。なお，別の設問できいた「高 校全入制」については，非期待派の方が賛成率は高い。ただし小学校教員の非期待派 を除くと，賛成率はさほど高くない。

\section{3. 要約}

以上報告してきたように，現下の教育改革論議について，三つの異なった世論が並 立している。第1は，国民一般の世論である。第 2 は, 一般教員層の「世論」である。 そして第 3 は，学校教育の世界で指導的地位にある管理職層の『世論』である。「数」 の点では, 第 1 の国民世論が最も大きく (有権者約 7,000 万人), 第 2 の「世論」は中 規模（小・中・高の教員総数は約 100 万人）であり，第 3 の『世論』は少数派である (小・中・高の校長数は約 4 万人)。一方，1 人あたりの意見の「力」では，逆に指導 層の『意見』が最も大きく，一般教員の「意見」が中間で，国民の意見は小さい。各 世論の政策決定への影響力は，「数」と単位意見の「力」の積によってきまると考え ると，上記の三つの世論は，ほぼ対等の「力」をもつことになる。 
この三つの世論は，前述したようにそれぞれ異なった様相を示している。学校教育 界の指導層の『世論』は, 臨教審の教育改革にかなり期待し, その基本的方向と各具 体案の多くに賛同しているとみられる。これに対し，一般教員大衆の「世論」は，概 して現下の教育改革に懐疑的であり，あまり期待もしていないし，各具体案に対して はむしろ否定的意見の方が多い。一方，一般国民の世論は，「業界」意見とは異なる 性格を有している。国民世論は，さむざまな意見が中和されてしまうので，そう鮮明 なものにはなりにくいが，教育に関しては，現状への不満も多く，現状打開への国民 の潜在的な関心は決して低くないと想像される。

このように異なる三つの世論が並立している状態が，現下の教育改革論議の性格を わかりにくくさせ，その見通しを不透明にしているように思われる。それぞれ有力な 一しかし決定的な力はもち得ない三つの世論は, ぞこに収斂してゆくのか，はたま た分裂，拡散してゆくのか，予断を許さないところである。

教育改革の帰趨は, 政治レベルでみれば,「力と数」によって決まってゆくのであ ろらが，事柄の性格上，それだけで結着をつけてもらいたくはない。それには，まず， 教育界（実践と研究の両者を含む）内部で, 教育論としての論議を重ね, 教育界内部 でのコンセンサスをつくる努力が必要であろう。そして，この「業界」意見と国民世 論のあいだで議論をつめて，改革の理念と政策を創出してゆくのが本筋であろう。

今回の臨教審による教育改革の審議方式は, この点で, 出発点から問題を抱えてい たといわざるを得ない。今からでも，教育界内の各階各層から，意見を汲み上げて論 議の中味を豊かにしてほしい。少なくとも, 一部の意見しか代表していない「圧力団 体」の意見を，教育界の多数意見と読み違えるようなことがあってはならない。どの 派, どの団体の意見が適切, 妥当と判断できるほどに, 教育界の論議はまだ煮つまっ ていない。教育改革に拙速は禁物である。本論文が，現下の教育改革構築の「足場」 を見直す一つの契機になれば幸いである。

\section{〈注〉}

(1) 本稿は, 昭和59年度文部省科学研究費＼cjkstart総合研究 $\mathrm{A} \cdot$ 課題番号59310039>「中学 校教員の役割不適応に関する実証的研究」, および昭和60年度文部省科学研究費<総 合研究 $\mathrm{A}$ ・課題番号60301035>「中学校教員の役割革新に関する総合的研究」の成 果の一部である。 なお，上記研究の成果は，下記に報告されている。

○松本良夫・河上婦志子「中学校教員の役割パターンと不適応」,『東京学芸大学 紀要』第 1 部門，第37集，1986年。

○ 松本良夫他「中学校教育の教職生活一七の意識と実態」(1) (6), 『中学教育』 昭和 60 年 7 月 12月号, 小学館。

○ 松本良夫他「中学校教員の退職危機の分析」, 東京学芸大学教育学教室編『教 育学研究年報』第 5 集, 1986年。

○ 松本良夫「教師は今, 何に悩んでいるか」『教育心理』昭和 61 年 2 月号, 日本 
文化科学社。

○松本良夫「中学校教師の “苦楽兄一小学校・高校と対比して」, 『月刊・教育 ジャーナル』昭和61年 6 月号, 学研。 